\title{
DEVELOPMENT OF COMMERCIAL FLAME RETARDANT IN UPHOLSTERY LEATHERS BY BORON DERIVATIVES
}

\author{
Safiye Meriç AÇIKEL \\ Istanbul University-Cerrahpaşa, Vocational School of Technical Sciences, \\ Leather Technology Program, Istanbul, TURKEY
}

Received: 31.07.2018

Accepted: 23.11.2018

\begin{abstract}
The production of flame retardant leather is significant for some leather types as aircraft and automotive upholstery leathers, and protective leathers as for motorcyclist jackets. For this reason, in this research it was aimed to modify effect of commercial flame retardant (CFR) on upholstery leathers treated with borax, boric acid and zinc borate. Control (group 1), $200 \mathrm{~g} / \mathrm{L}$ CFR (group 2), $10 \mathrm{~g} / \mathrm{L}$ borax $+60 \mathrm{~g} / \mathrm{L}$ boric acid $+200 \mathrm{~g} / \mathrm{L}$ CFR (group 3) and $10 \mathrm{~g} / \mathrm{L}$ zinc borate $+60 \mathrm{~g} / \mathrm{L}$ boric acid $+200 \mathrm{~g} / \mathrm{L} \mathrm{CFR} \mathrm{(group} \mathrm{4)} \mathrm{chemical}$ solutions were applied to the leathers by padding finishing technique, and after the flame retardant application the leathers were finished with traditional finishing recipe. Flame retardant property of leathers was determined by vertical flammability (ISO 6941:2007) and limit oxygen index (LOI) (ASTM D 2863-77) fire resistance tests. In addition, the treated leathers were characterized by ATR-FTIR and SEM devices. According to LOI results, CFR CFR+borax+boric acid and CFR+zinc borate+boric acid treated groups of leather had $28.5 \%, 29.2 \%$ and $29.9 \%$ oxygen concentration respectively, while control sample had $27.0 \%$. Flame retardant property of leathers was significantly enhanced by the effect of boron derivatives.
\end{abstract}

Keywords: Leather, Flame Retardant, Fire, LOI, Borax, Zinc Borate

Corresponding Author: Safiye Meriç AÇIKEL, e-mail: safiye.acikel@istanbul.edu.tr, / DOI: 10.32710/ tekstilvekonfeksiyon.493101

\section{INTRODUCTION}

Leather used in every area of life and comes up to today from ancient times, has a production model which is different from textile production. In leather production, the natural reactive groups of leather are modified with various chemicals such as chrome, vegetable tannins, synthetic agents, and various leather products such as shoes, garments, goods, upholstery have been manufactured [1, 2]. Nowadays, upholstery leather types are used in areas such as furniture, aviation, automotive and motorcycle, and often are desired resistance to light, rubbing, and some fastness properties, besides, the recent demand has been directed to the flame resistance of leather [3,4]. Literature scan has shown that there are few studies about the flame retardancy feature and it is provided with a few commercial products in leather industry. Therefore, new chemicals or compounds should be developed to gain in time to rescue humans and animals during the fire $[5,6]$. Flame retardants are classified as halogen containing flame retardants (chlorated compounds, bromated compounds, etc.), halogen-free flame retardants (ammonium phosphate, organo phosphorus compounds, inorganic phosphorus compounds, etc.), nanocomposites and mineral substances (borax, boron, boric acid, zinc borate, aluminum hydroxide, magnesium hydroxide, etc.) $[7,8]$. Boron and derivatives, which are cheaper and less toxic than other flame retardants, constitute an impenetrable glass coating form in material surface during thermal degradation and prevent further propagation of combustion. Additionally, the hydrated water from borax and derivatives absorbs the thermal energy of the flame $[9,10,11]$. In this study, it was aimed to modify the commercial flame retardant chemical with boron derivatives and to investigate their flame retardant effects on leather.

\section{MATERIAL AND METHODS}

\subsection{Materials}

The upholstery leathers (blue color, cattle hide) without finishing were supplied from the leather company in Tuzla Leather Industrial Area. Boric acid $\left(\mathrm{H}_{3} \mathrm{BO}_{3}\right)(99 \%$, extra pure) and Borax $\left(\mathrm{Na}_{2} \mathrm{~B}_{4} \mathrm{O}_{7} .10 \mathrm{H}_{2} \mathrm{O}\right)(99 \%$, extra pure) were purchased from Tekkim Ltd. Chemical Company (Turkey) and Zinc borate $\left(\mathrm{Zn}_{3} \mathrm{BO}_{6}\right)$ was supplied from Kimetsan Ltd. Chemical Company (Turkey). Commercial Flame Retardant (CFR) containing of AOX free inorganic halogen was used in the experiments. In the finishing recipe different chemicals were used: Sarpur 317 (Sarchem b.v.) as polyurethane binder, Saracryl 588 (Sarchem b.v.) as acrylic binder, Sarfill 8537 (Sarchem b.v.) as filler, Sarkol K Black 
(Sarchem b.v.) as blue Pigment, Sarwaks 8147 (Sarchem b.v.) as wax, Selladerm Blue (TFL Company) as aniline dye, Sartop 118 (Sarchem b.v.) as protein binder, Melio EW 348B (Clariant b.v.) as hydrolacque, Melio WF 5226 (Clariant b.v.) as feeling agent.

\subsection{Methods}

The flame retardant solutions given in Table 1 were prepared according to methods described by Wang et al. [11]. In brief, borax, boric acid and zinc borate were dissolved in distilled water and the solutions were stirred for 30 minutes at $40^{\circ} \mathrm{C}$. The solution were mixed according to rates given in Table 1 and were stirred again for 30 minutes at $40{ }^{\circ} \mathrm{C}$ to obtain homogeneous mixture [11]. Leather Padding Technique which is a kind of finishing technique made by hand is used for the intense or decorative pattern finishing applications. Chemical solutions were applied to leathers at different concentrations by this technique. All leathers were dried at the room temperature for $24 \mathrm{~h}$ and then same application was repeated once again $[12,13]$.

After application of the proposed flame retardant mixture, the leather samples were finished with the standard finishing recipe given in Table 2 . The treated leather samples were cut into 5 pieces $170 \times 560 \mathrm{~mm}$ sized for the vertical flammability test and 15 pieces $140 \mathrm{~mm}$ x $60 \mathrm{~mm}$ sized for LOI test.

Table 1. The Constituents of the Flame-Retardant Finishing Bath

\begin{tabular}{|l|c|c|c|c|}
\hline Chemical & $\begin{array}{c}\text { Group } \\
\mathbf{1}(\mathbf{g} / \mathbf{L})\end{array}$ & $\begin{array}{c}\text { Group 2 } \\
\text { (g/L) }\end{array}$ & $\begin{array}{c}\text { Group 3 } \\
\text { (g/L) }\end{array}$ & $\begin{array}{c}\text { Group 4 } \\
\text { (g/L) }\end{array}$ \\
\hline $\begin{array}{l}\text { Commercial Flame } \\
\text { Retardant (CFR) }\end{array}$ & 0 & 200 & 200 & 200 \\
\hline Borax & 0 & 0 & 10 & 0 \\
\hline Boric Acid & 0 & 0 & 60 & 60 \\
\hline Zinc Borate & 0 & 0 & 0 & 10 \\
\hline
\end{tabular}

Table 2. Finishing Recipe of the Flame Retardant Applied Leathers

\begin{tabular}{|c|c|c|}
\hline Chemical & Rate & Finishing Application \\
\hline Polyurethane Binder (g) & 100 & \multirow{8}{*}{$\begin{array}{l}\text { 2x Spray } \\
\text { Press } \\
\left(70 \text { atm, } 90^{\circ} \mathrm{C}, 1 \mathrm{sn}\right) \\
1 \mathrm{x} \text { Spray } \\
\text { Press } \\
\left(70 \mathrm{~atm}, 90^{\circ} \mathrm{C}, 1 \mathrm{sn}\right)\end{array}$} \\
\hline Acrylic Binder (g) & 75 & \\
\hline Protein Binder (g) & 75 & \\
\hline Filler $(\mathrm{g})$ & 50 & \\
\hline Waks $(\mathrm{g})$ & 75 & \\
\hline Pigment Dye (g) & 80 & \\
\hline Anilin Dye (g) & 20 & \\
\hline Water $(\mathrm{g})$ & 500 & \\
\hline Hydrolaque (g) & 100 & \multirow{3}{*}{$\begin{array}{l}1 \times \text { Spray } \\
\text { Press } \\
\left(70 \text { atm, } 90^{\circ} \mathrm{C}, 1 \mathrm{sn}\right)\end{array}$} \\
\hline Feeling Agent (g) & 10 & \\
\hline Water (g) & 150 & \\
\hline
\end{tabular}

\subsection{Measurements}

Before performing the flammability test, the leather samples were conditioned at a temperature of $20 \pm 2^{\circ} \mathrm{C}$ and a relative humidity of $65 \pm 4 \%$. For the vertical flammability test, the samples were placed in a rectangular frame in a vertical position [14]. Vertical flammability test was performed at $21^{\circ} \mathrm{C}$ temperature and $57 \%$ relative humidity. Butane gas was used for the test. The leather samples were exposed for $10 \mathrm{~min}$ at $40 \mathrm{~mm}$ flame height and contacted with flame situated perpendicularly to the sample surface or directly below the sample edge. Limit oxygen index (LOI) tests were performed on a limiting oxygen index chamber with strips of the material according to ASTM D 2863-77 [15]. For SEM analysis the samples were placed on a scanning electron microscope (Fei-Quanta Feg 250) and their images were taken at $100 \mu \mathrm{m}$ and $20 \mu \mathrm{m}$ magnifications. FTIR analysis was conducted in order to determine the differences in the chemical properties of leather treated with flame retardants and the control (group 1). FTIR studies were conducted on Bruker-Vertex70 ATR device with ATR equipment. For this purpose, the leather samples were scanned with IR spectrums at a wavelength of $4000-600 \mathrm{~cm}^{-1}$ and the results were evaluated in the FTIR Spectrum Software and compared with the spectrums in the literature. A Konica Minolta CM-508D brand global spectrophotometer with an 8 $\mathrm{mm}$ diameter measurement area was used in the measurement of the leather dyes. Measurements were taken from 10 different areas of each leathers according to CIE Lab (1976) and the color differences were determined between treated and untreated leathers in CIE 100 standard observer angle and CIE standard D65 light source. In the components of the CIE Lab color space, $L^{*}$ is the lightness of color, and $a^{*}$ and $b^{*}$ indicate the color [16]. If $L^{*}$ has a negative value, it means that the color of sample has darkened, while if it has a positive value, it means that the sample color has turned lighter. $\Delta \mathrm{L}$ is darkness or lightness difference, $\Delta \mathrm{a}$ is redness and greenness difference and $\Delta \mathrm{b}$ is yellowness and blueness difference between the control (group 1) and the other groups. $\Delta \mathrm{E}$, which is total color difference, is calculated according to the following equation (1) [17].

$\Delta \mathrm{E}=\left[\left(\Delta \mathrm{L}^{*}\right) 2+\left(\Delta \mathrm{a}^{*}\right) 2+\left(\Delta \mathrm{b}^{*}\right) 2\right] 1 / 2$

To perform the physical tests, the treated leathers were conditioned under standard atmospheric conditions as recommended in EN ISO 2419 at a temperature of $23^{\circ} \mathrm{C} \pm$ $2^{\circ} \mathrm{C}$ and $50 \% \pm 5 \%$ relative humidity, and sampling locations were carried out according to EN ISO 2418 [18, 19]. Thickness identification of the samples was made according to EN ISO 2589 [20]. Determination of the tensile strength, the percentage extension and the double edge tear load of the samples was performed according to EN ISO 3376 and EN ISO 3377-2 respectively, using Shimadzu AG-IS Test Apparatus [21, 22].

\section{RESULTS AND DISCUSSION}

\subsection{The LOI Results of the Treated Leathers}

Natural leather products generally have higher flame retardancy as compared to fabrics, artificial leather and other leather types. Accordingly, researchers have observed that natural leather (the control group) shows very high LOI result in the incombustibility studies made with textile products [23]. In this study, the flame retardant property of the leathers treated with the commercial flame retardant was significantly increased by the effect of borax and its derivatives. LOI results of the leather samples are given in Table 3. The results showed $28.5 \%$ for group $2,29.2 \%$ for group 3 and $29.9 \%$ for group 4 , while for group $127.0 \%$ of LOI value was obtained. The highest LOI value for the fire 
retardant solution was achieved when $200 \mathrm{~g} / \mathrm{L}$ of $\mathrm{CFR}$, $60 \mathrm{~g} / \mathrm{L}$ of zinc borate and $10 \mathrm{~g} / \mathrm{L}$ of boric acid were used.

Table 3. The LOI Test Results of the Treated Leathers

\begin{tabular}{|c|c|}
\hline Group & LOI (\%) \\
\hline 1 & 27.0 \\
\hline 2 & 28.5 \\
\hline 3 & 29.2 \\
\hline 4 & 29.9 \\
\hline
\end{tabular}

The flame retardancy results obtained in this study for the treated leathers were compared with some results determined in different studies. For instance, Zang, et al. (2018) used the phosphorus-nitrogen containing waterborne polyurethane/graphene nanocomposite (PN/G-WPU) in retanning process of the chrome tanned cattle leathers and maximum $26.3 \%$ LOI value for the treated leathers was obtained [24]. Lyu et al. used the nanocomposite based on erucic acid modified montmorillonite/sulfited rapeseed oil in fatliquoring process of the flame retardant leather product and they found maximum $27.9 \% \mathrm{LOI}$ value in the leather samples [25]. Açıkel (2018) was found maximum 30.5\% LOI value for $24 \%$ tributyl phosphate (TBP) applied upholstery leathers [13]. In another study, Açıkel et al. (2018) have investigated the flame retardant property of vegetable tanned leathers and they found that leather tanned with tara and treated with $21 \%$ tributyl phosphate showed $34.9 \%$ LOI value and for leather tanned with mimosa and treated with $21 \%$ tributyl phosphate $39.7 \%$ LOI result was obtained These high LOI results were related to the high content of the hydrophilic hydroxyl groups in the molecular structure of vegetable tannins, and the moisture or water have delayed the burning behavior of that leathers [26]. In this study, the comparable LOI values for the leathers treated with CFR and boron derivatives were detected and the highest LOI value was almost close to the values obtained with TBP
[13]. In addition, these values were obtained without the contribution of vegetable tanning.

\subsection{The Vertical Flammability Test Results of the Treated Leathers}

The vertical flammability test results are presented in Table 4. According to the results, the vertical flammability of the control group showed 0 second for the flame expansion time, $65 \mathrm{~s}$ for the flame combustion time and approximately $15 \mathrm{~min} 13 \mathrm{~s}$ for the flameless combustion time when the flame was edge situated. However, the vertical flammability of the other groups was observed as for non-ignitable materials (with the combustion time: $0 \mathrm{~mm} / \mathrm{min}$ ). This result is thought to be attributed to the fact that the phosphorous in the commercial flame retardant and boron chemicals possibly showed synergic effect and the ignition of the leather fibers was prevented by this effect $[12,13]$.

\subsection{ATR-FTIR Analysis of Leathers}

ATR-FTIR analysis results of the leathers are displayed in Figure 1. According to the results, some characteristic peaks of leather were obtained at $1730 \mathrm{~cm}^{-1}$ (vibration of $\mathrm{C}=\mathrm{O} \mathrm{C}-\mathrm{N}$ group), at $1453 \mathrm{~cm}^{-1}, 1374 \mathrm{~cm}^{-1}$ and $1541 \mathrm{~cm}^{-1}$ (a mixture of $\mathrm{N}-\mathrm{H}, \mathrm{C}-\mathrm{N}, \mathrm{C}-\mathrm{C}$ ), at $3317 \mathrm{~cm}^{-1}$ and $2921 \mathrm{~cm}^{-1}$ (consists of asymmetric $\mathrm{CH} 2$ groups) [12, 13]. Besides, the leathers from group 2 showed the sharp peaks at $1277 \mathrm{~cm}^{-1}$ $(P=O)$ and $840 \mathrm{~cm}^{-1}(\mathrm{P}-\mathrm{O})$ due to the fact that CFR is probably containing phosphorous compounds. In addition, the peaks at $1644 \mathrm{~cm}^{-1}, 1451 \mathrm{~cm}^{-1}$ and $1065 \mathrm{~cm}^{-1}$ in the FTIR graphics of group 3 and group 4 were consistent with the characteristic asymmetrical stretching peak of $\mathrm{B}-\mathrm{O}$. Furthermore, the peak observed at $835 \mathrm{~cm}^{-1}$ was attributed to the symmetrical stretching of B3-O. And also the peaks at $749 \mathrm{~cm}^{-1}$ and $687 \mathrm{~cm}^{-1}$ were occurred because of stretching vibration of $\mathrm{B}_{3}-\mathrm{O}[27,28]$.

Table 4. The Vertical Flammability Test Results of the Treated Leathers

\begin{tabular}{|l|l|l|l|l|}
\hline Group & $\begin{array}{l}\text { Flame Expansion } \\
\text { Time (s) }\end{array}$ & Ignition & $\begin{array}{l}\text { Flame Combustion } \\
\text { Time (s) }\end{array}$ & $\begin{array}{l}\text { Flameless Combustion } \\
\text { Time (s) }\end{array}$ \\
\hline 1 & 0 & Ignition & 65 & 15 min 13 s \\
\hline 2 & 0 & Non Ignition & - & - \\
\hline 3 & 0 & Non Ignition & - & - \\
\hline 4 & 0 & Non Ignition & - & - \\
\hline
\end{tabular}

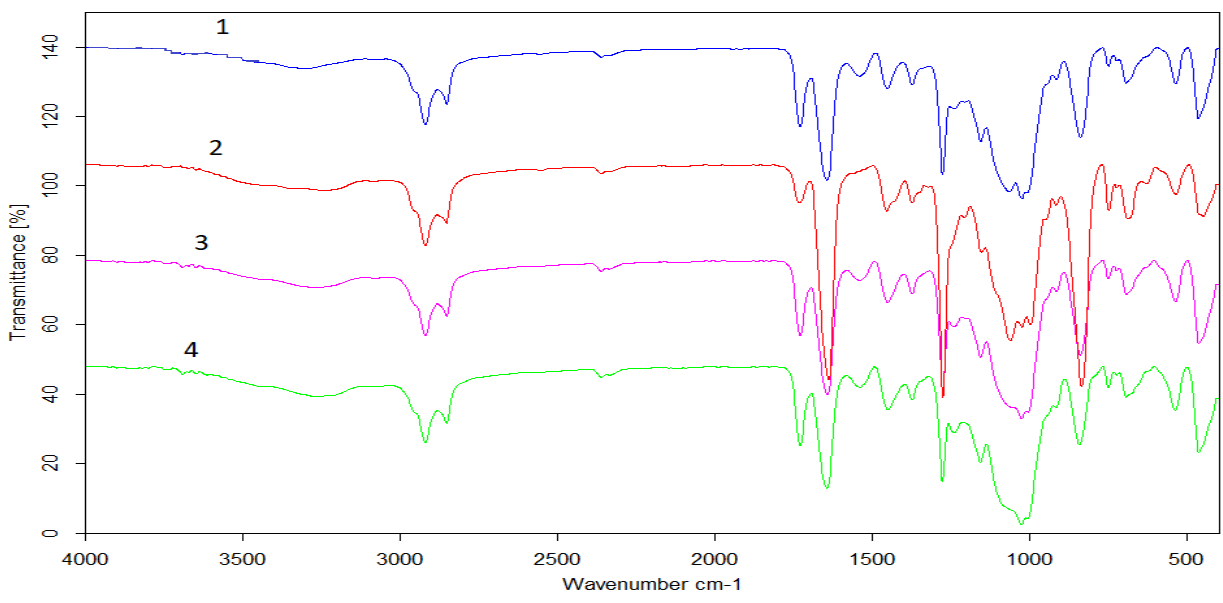

Figure 1. ATR-FTIR Spectra of The Flame Retardant Treated Leathers 


\subsection{Surface Morphology of Leathers}

SEM images with $100 \mu \mathrm{m}$ and $50 \mu \mathrm{m}$ magnifications of the flame retardant applied leathers after finishing application are exhibited in Figure 2. These images show that significantly changing on the surfaces of the leather samples has not been observed and the deformations on the surfaces of the leathers were similarly the same. Therefore, the application of boron derivatives would not cause any damage problems on leathers and it can be used easily for any kind of leathers.

\subsection{Physical properties of leathers}

Leathers should have enough strength properties, depending on the application field. Acceptable quality standards recommended by United Nations Industrial Development Organization (UNIDO) for the upholstery leathers offer minimum of $20 \mathrm{~N} / \mathrm{mm}^{2}$ for the tensile strength, maximum of $75 \%$ for the tensile extension and minimum of $100 \mathrm{~N}$ for the double edge tear load [29]. The physical properties of leathers results of the leathers treated with the flame retardants are given in Table 5 . The tensile strength values obtained for the treated leather samples are varied from $17.7 \mathrm{~N} / \mathrm{mm}^{2}$ to $10.4 \mathrm{~N} / \mathrm{mm}^{2}$. However, all groups show lower values than acceptable UNIDO value. Tear extension values obtained from all leathers were lower than the extension limit of $75 \%$ indicated by UNIDO. The results showed that the CFR, borax and zinc borate cause reduction of the physical properties at acceptable limiting values.

\subsection{Color Changing of Leather by CIE Lab Analysis}

Table 6 shows the results of CIE Lab after the flame retardant was applied to the upholstery leathers in different groups. When CIE Lab values of the leathers were examined; it was seen that $\Delta a$ values, being redness and greenness, were changed from 1.57 to 0.09 . It is mean that redness effect of leathers was raised by CFR, borax, and zinc borate. $\Delta b$ values, being yellowness and blueness, were observed 0.10 for group 2, 0.87 for group 3 and -0.84 for group 4. It means that borax and CFR increased blueness effect, while zinc borate caused yellowness on the upholstery leathers. $\Delta \mathrm{L}$ values in group 3 and group 4 were similar and borax and zinc borate showed lightness effect on the leathers.
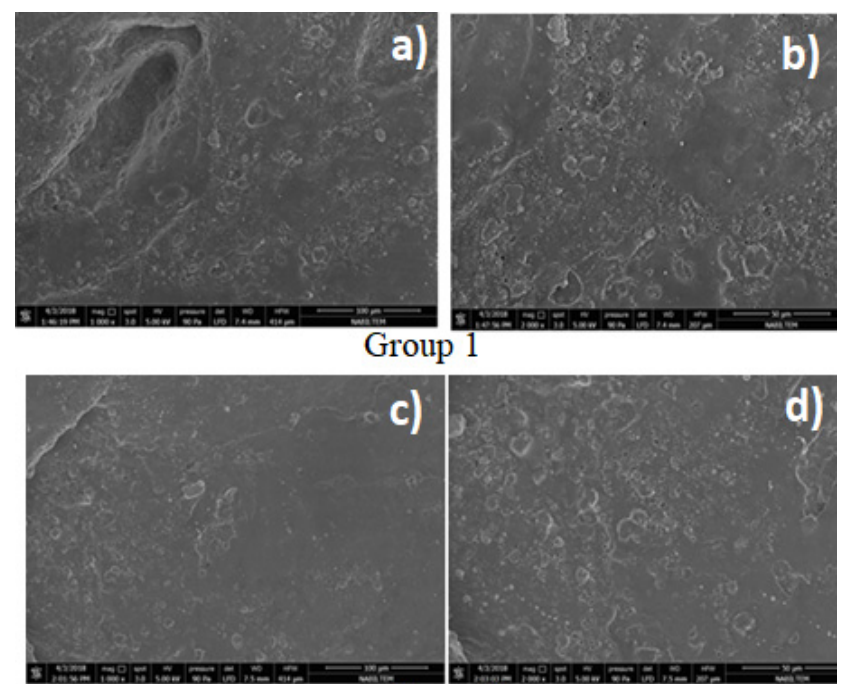

Group 2

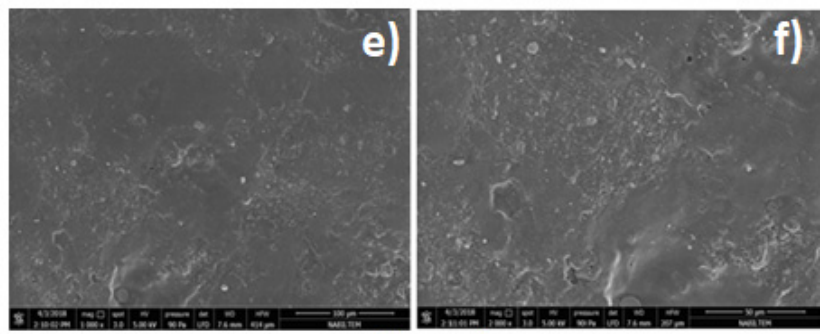

Group 3

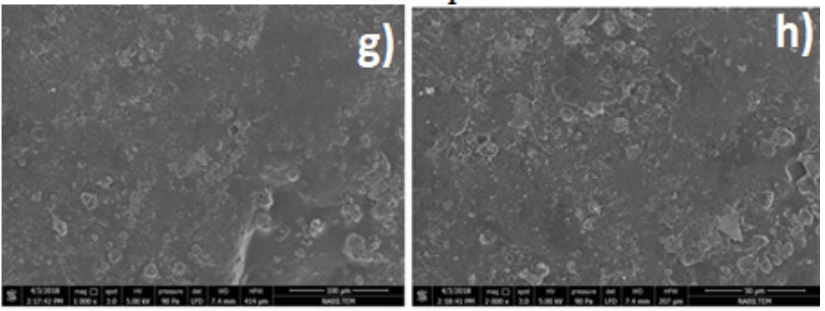

Group 4

Figure 2. SEM images of the Treated Leather Samples with 50 $\mu \mathrm{m}(\mathrm{a}, \mathrm{c}, \mathrm{e}, \mathrm{g})$ and $100 \mu \mathrm{m}(\mathrm{b}, \mathrm{d}, \mathrm{f}, \mathrm{h})$ Magnification

Table 5. Mechanical Properties of Leathers

\begin{tabular}{|c|c|c|c|c|c|c|c|c|}
\hline Group & \multicolumn{2}{|c|}{$\begin{array}{c}\text { Tensile Strength } \\
\left(\mathbf{N} / \mathbf{m m}^{2} \text { ) }\right.\end{array}$} & \multicolumn{2}{c|}{$\begin{array}{c}\text { Percentage } \\
\text { Extension (\%) }\end{array}$} & \multicolumn{2}{c|}{$\begin{array}{c}\text { Tear Load } \\
\text { (N/mm) }\end{array}$} & \multicolumn{2}{c|}{$\begin{array}{c}\text { Thickness } \\
\text { (mm) }\end{array}$} \\
\hline & Vertical & Parallel & Vertical & Parallel & Vertical & Parallel & Vertical & Parallel \\
\hline 1 & 17.7 & 15.1 & 70.2 & 70.4 & 163.7 & 147.5 & 1.7 & 1.5 \\
\hline 2 & 13.5 & 13.8 & 72.9 & 71.3 & 168.4 & 136.5 & 1.6 & 1.7 \\
\hline 3 & 10.6 & 11.3 & 74.4 & 72.9 & 137.5 & 113.2 & 1.9 & 2.0 \\
\hline 4 & 10.4 & 10.8 & 74.1 & 74.9 & 100.1 & 102.9 & 1.7 & 1.8 \\
\hline
\end{tabular}

Table 6. CIE Lab Results of Leathers

\begin{tabular}{|c|c|c|c|c|c|c|c|}
\hline Group & $\mathbf{L}^{*}(\mathbf{D 6 5})$ & $\mathbf{a}^{*}(\mathbf{D} 65)$ & $\mathbf{b}^{*}$ (D65) & $\mathbf{\Delta L}$ & $\mathbf{\Delta a}$ & $\mathbf{\Delta} \mathbf{b}$ & $\mathbf{\Delta E}$ \\
\hline 1 & 35.32 & -1.71 & -20.09 & - & - & - & - \\
\hline 2 & 33.19 & -0.13 & -19.99 & -2.13 & 1.57 & 0.10 & 2.65 \\
\hline 3 & 34.48 & -1.61 & -19.22 & -0.84 & 0.09 & 0.87 & 1.21 \\
\hline 4 & 34.48 & -0.89 & -20.93 & -0.84 & 0.82 & -0.84 & 1.44 \\
\hline
\end{tabular}




\section{CONCLUSIONS}

In this study, the development of the flame retardant effect of commercial chemical by boron derivatives on the surface of leathers was investigated. According to the obtained results, the leather samples from group 4 to which $200 \mathrm{~g} / \mathrm{L}$ of CFR, $60 \mathrm{~g} / \mathrm{L}$ of zinc borate and $10 \mathrm{~g} / \mathrm{L}$ of boric acid solution were applied, showed $29.9 \%$ LOI value, the effective flame retardant property in LOI tests. Especially in the vertical flammability test results, all groups of leathers displayed non-ignitable material property by the synergic effects of chemicals. In addition, lightness effect in all groups was increased by the effect of the flame retardant chemicals, while the physical properties of leathers was reduced in all leather groups. Consequently; it was considered that Boron treatment with commercial chemical could be a better alternative method for being used as a flame retardant pre-treatment of leathers when compared to conventional processes. It can be concluded that borax and zinc borate can be applied to leather products before finishing and in our further studies application of different concentrations of these compounds will be investigated.

\section{REFERENCES}

1. Duan B.R. and Wang Q.J., 2012, "Influence of Flame Retardant on Leather Fatliquoring and Fire Resistance", ICEMMA, Vol: 487, pp:748-752.

2. Jiang Y., Li j., Li B., Liu H., Li Z., Li L., 2015, "Study On a Novel Multifunctional Nanocomposite As Flame Retardant of Leather", Polymer Degradation and Stability, Vol:115, pp:110-116.

3. Donmez K. and Kallenberger W.E., 1991, "An Overview of Testing of Leather for Flame Glow Retardation", Journal American Leather Chemists Association, Vol:86 (3), pp:93-106.

4. $\quad$ Yang L.T., Liu Y., Wu Y.J., Deng L.L. Liu W., Ma C.P., Li L.X., 2016, "Thermal degradation kinetics of leather fibers treated with fire-retardant melamine resin", Journal of Thermal Analysis and Calorimetry, Vol:123(1), pp:413-420.

5. Fabian T., 2013, "Upholstered Furniture Flammability", Fire Hazards Manager-Corporate Research, Vol:1, pp:46.

6. Huang Z., Li L.X., Wang Y.H., Lin Y.Z., Chen W.Y., 2005, "Performance of flame retardants on leather", Journal of The Society of Leather Technologists and Chemists, Vol:89(6), pp:225-231.

7. Schartel B. 2010, “Phosphorus-based Flame Retardancy Mechanisms-Old Hat or a Starting Point for Future Development?”, Materials, Vol:3, pp:47104745.

8. Schmitt E., 2007, "Flame retardants Phosphorus-based flame retardants for thermoplastics", Plastics Additives and Compounding, Vol:9(3), pp:26-30.

9. Çakal G.Ö., Göğebakan Z., Coşkun S., 2012, "Investigation of Synergistic Effect of Boron on Fire Retardancy of Cotton Fabrics", Textile and Apparel, Vol:18 (4), pp:547-553.

10. Akarslan F., 2015, "Investigation on Fire Retardancy Properties of Boric Acid Doped Textile Materials", Acta Physica Polonica Series a, Vol:128, pp:403405 .

11. Wang X., Lu C., Chen C., 2014, "Effect of Chicken-Feather Protein-Based Flame Retardant on Flame Retarding Performance of Cotton Fabric", Journal of Applied Polymer Science, Vol:131(15), pp:40584-40592.

12. Açıkel S.M., 2018, "Researching of Properties of Gained Flame Retardancy on the Upholstery Leathers by Tributyl Phosphate Chemical", Sakarya University Journal of Science, Vol:22(5), pp:1-7.

13. Açikel S.M., Çelik C., Gültek A.S., Aslan A., 2017, "The Flame Retardant Effect of Tributyl Phosphate On The Leathers", International Journal of Scientific and Technology Research, Vol:6, pp:44-48.

14. EN ISO 6941:2007, 2007, "Vertical-Textile Fabrics-Burning Behaviour", International Organization for Standardization.

15. ASTM D 2863-77, 2006, "Standard Test Method for Measuring the Minimum Oxygen Concentration to Support Candle-Like Combustion of Plastics (Oxygen Index)", American Society for Testing and Materials.

16. Mclaren, K., 1976, "XIII-The Development of the CIE $1976\left(L^{*} a^{*} b^{*}\right)$ Uniform Colour Space and Colour - difference Formula", Coloration Technologhy, vol:92(9), pp:338-341.

17. Brainard D.H., in: Shevell S.K. (Ed.), 2003, "Color Appearance and Color Difference Specification", The Science of Color, 2nd ed., OSA and Elsevier, Oxford.

18. EN ISO 2419, 2012, "Leather Physical and mechanical tests Sample preparation and conditioning", International Organization for Standardization.

19. EN ISO 2418, 2002, "Leather Chemical, physical and mechanical and fastness tests Sampling location”, International Organization for Standardization.

20. EN ISO 2589, 2016, "Leather - Physical and mechanical tests - Determination of thickness", International Organization for Standardization.

21. EN ISO 3376, 2002, "Leather - Physical and mechanical tests - Determination of tensile strength and percentage extension", International Organization for Standardization.

22. EN ISO 3377-2, 2002, "Leather -- Physical and mechanical tests -- Determination of tear load -- Part 2: Double edge tear", International Organization for Standardization.

23. Bacardit A., Borras M.D., Soler J., Herrero V., Jorge J., Olle L., 2010, "Behavior of Leather As A Protective Heat Barrier and Fire Resistant Materia", Journal American Leather Chemists Association, Vol:105(2), pp:51-61.

24. Zhang P., Xu P., Fan H., Zhang Z., Chen Y., 2018, "Phosphorus-nitrogen Flame Retardant Waterborne Polyurethane/Graphene Nanocomposite for Leather Retanning", Journal American Leather Chemists Association, Vol:113, pp:142-150.

25. Lyu B., Gao J., Ma J., Gao D., Wang H., Han X., 2016, "Nanocomposite based on erucic acid modified montmorillonite/sulfited rapeseed oil: Preparation and application in leather", Applied Clay Science, Vol:121-122, pp:36-45.

26. Açıkel S.M., Çelik C., Gürbüz D., Çınarlı A., 2018, "Flame Retardant Effect of Tri Butyl Phosphate (TBP) in Vegetable Tanned Leathers", Textile and Apparel, Vol:28(2), pp:135-140.

27. Karel G. P., Carmencita O.L., Ramos, H.J., 2012, "Plasma impregnation of wood with fire retardants", Nuclear Instruments and Methods in Physics Research B, Vol:272, pp:365-369.

28. Xie W., Zoua C., Tanga Z., Fub H., Zhua X., Kuanga J., Denga Y., 2017, "Well-crystallized borax prepared from boron-bearing tailings by sodium roasting and pressure leaching", RSC Advances, Vol:7, pp:31042-31048.

29. UNIDO, 1996, "Acceptable Quality Standards in the Leather and Footwear Industry", United Nations Industrial Development Organization, Vienna. 
